\title{
OPTIMASI PEMUPUKAN PADI GOGO SEBAGAI TANAMAN SELA TANAMAN KARET BELUM MENGHASILKAN
}

\author{
Optimization of Upland Rice Fertilization as an Intercrops in Immature Rubber Plantation \\ Sahuri $^{1}$, Nurmansyah ${ }^{2}$, Iman Satra Nugraha ${ }^{3}$ dan Aprizal Alamsyah ${ }^{4}$ \\ ${ }^{1,3,4}$ Balai Penelitian Sembawa, Pusat Penelitian Karet \\ ${ }^{2}$ Plant Production Department, College of Food and Agriculture, King Saud University \\ J1. Raya Palembang-Betung Km 29, Palembang 30001, Indonesia \\ Email : sahuri_agr@ymail.com
}

Diterima 9 Januari 2019 / Direvisi 7 Februari 2019 / Disetujui 11 Maret 2019

\begin{abstract}
Abstrak
Penanaman padi gogo di gawangan karet sebagai alternatif untuk meningkatkan produktivitas lahan dan pendapatan petani. Penelitian ini bertujuan mendapatkan paket pemupukan NPK padi gogo sebagai tanaman sela karet dan mengetahui pengaruh tumpangsari padi gogo terhadap pertumbuhan karet klon PB 340. Penelitian dilaksanakan di Kebun Percobaan Balai Penelitian Sembawa dari bulan November 2016 sampai Maret 2017. Penelitian menggunakan rancangan petak terpisah, 3 ulangan. Petak utama adalah kombinasi pupuk $\mathrm{P}$ dan $\mathrm{K}$, 4 perlakuan: 1$) 0 \mathrm{~kg}$ $\left.\mathrm{P}_{2} \mathrm{O}_{5} / \mathrm{ha}+0 \mathrm{~kg} \mathrm{~K}_{2} \mathrm{O} / \mathrm{ha}, 2\right) 36 \mathrm{~kg} \mathrm{P}_{2} \mathrm{O}_{5} / \mathrm{ha}+0$ $\mathrm{kg} \mathrm{K}_{2} \mathrm{O} / \mathrm{ha}$, 3) $0 \mathrm{~kg} \mathrm{P}_{2} \mathrm{O}_{5} / \mathrm{ha}+60 \mathrm{~kg} \mathrm{~K}_{2} \mathrm{O} / \mathrm{ha}$, dan 4) $36 \mathrm{~kg} \mathrm{P}_{2} \mathrm{O}_{5} / \mathrm{ha}+60 \mathrm{~kg} \mathrm{~K} 2 \mathrm{O} / \mathrm{ha}$. Anak petak adalah pemberian pupuk $\mathrm{N}$ dengan 4 perlakuan: 1) 0, 45, 90, dan $135 \mathrm{~kg} \mathrm{~N} /$ ha. Hasil penelitian menunjukkan bahwa tumpangsari padi gogo berpengaruh terhadap peningkatan produktivitas lahan dan pertumbuhan karet. Kombinasi pupuk NPK yang optimal untuk meningkatkan pertumbuhan dan hasil padi gogo sebagai tanaman sela karet adalah $(90 \mathrm{~kg}$ $\left.\mathrm{N} / \mathrm{ha}+36 \mathrm{~kg}_{2} \mathrm{O}_{5} / \mathrm{ha}+60 \mathrm{~kg} \mathrm{~K}_{2} \mathrm{O} / \mathrm{ha}\right)$.
\end{abstract}

Kata kunci : Karet, padi gogo, produktivitas lahan, pupuk NPK, tanaman sela

\section{Abstract}

The planting of upland rice in the between row of immature rubber period as an alternative to increase land productivity and income of farmers. The objective of this research were to get packages of NPK fertilization on the upland rice as rubber intercrops and to study the effect of rubber + upland rice intercropping system on the rubber growth of clones PB 340. The experiment was conducted at the Sembawa Research Station from November 2016 through March 2017. The experiment was used split plot design, three replications. The main plot was a combination of $\mathrm{P}$ and $\mathrm{K}$, 4 treatments: 1) $0 \mathrm{~kg} \mathrm{P}_{2} \mathrm{O}_{5} /$ $\mathrm{ha}+0 \mathrm{~kg} \mathrm{~K} \mathrm{O}_{2} \mathrm{O} / \mathrm{ha}$, 2) $36 \mathrm{~kg} \mathrm{P}_{2} \mathrm{O}_{5} / \mathrm{ha}+0 \mathrm{~kg} \mathrm{~K}_{2} \mathrm{O} /$ $\mathrm{ha}$, 3) $0 \mathrm{~kg} \mathrm{P} \mathrm{O}_{5} / \mathrm{ha}+60 \mathrm{~kg} \mathrm{~K} \mathrm{~K}_{2} \mathrm{O} / \mathrm{ha}$, and 4) $36 \mathrm{~kg}$ $\mathrm{P}_{2} \mathrm{O}_{5} / \mathrm{ha}+60 \mathrm{~kg} \mathrm{~K} \mathrm{O} / \mathrm{ha}$. The subplots were $\mathrm{N}$ fertilizer with 4 treatments: 1) 0, 45, 90, and $135 \mathrm{~kg}$ $N$ / ha. The results showed that upland rice intercropping had a positive effect on improvement the growth of rubber tree PB 340 clones and land productivity. The combination of NPK optimum to improve the growth and yield of upland rice as rubber intercrops was $90 \mathrm{~kg} \mathrm{~N} / \mathrm{ha}+36 \mathrm{~kg} \mathrm{P}_{2} \mathrm{O}_{5} / \mathrm{ha}$ $+60 \mathrm{~kg} \mathrm{~K} \mathrm{O} / \mathrm{ha}$ ).

Key words : Rubber, upland rice, land productivity, NPK Fertilizer, intercrops

\section{Pendahuluan}

Penanaman padi gogo di gawangan tanaman karet belum menghasilkan (TBM) sebagai alternatif untuk meningkatkan produktivitas lahan dan pendapatan petani karet (Wibawa \& Rosyid, 1995; Zuraida, 2014). Budidaya padi gogo di gawangan karet merupakan pilihan yang banyak diminati dan telah lama dipraktekkan oleh petani. Namun produktivitas dengan sistem tersebut masih sangat rendah dibandingkan dengan 
produktivitas padi sawah (Pirngadi et al., 2007; Sasmita et al., 2006). Hal ini karena areal tanaman karet umumnya banyak terdapat di lahan kering ultisol dengan lapisan top soil tipis antara $5-15 \mathrm{~cm}$, miskin bahan organik, miskin hara $\mathrm{N}, \mathrm{P}, \mathrm{K}, \mathrm{Mg}, \mathrm{Ca}$, kemasaman tinggi karena kadar alumunium (Al), dan besi (Fe) yang tinggi sehingga menghambat pertumbuhan akar tanam a n (Notohadiprawiro, 2006; Prasetyo \& Suriadikarta, 2006; Santoso, 2006; Wijaya, 2008; Paiman \& Armando, 2010; Syahputra et al., 2015). Oleh karena itu, diperlukan perbaikan kesuburan tanah melalui aplikasi kapur dan bahan organik, pemupukan hara $\mathrm{N}$, $\mathrm{P}$, dan $\mathrm{K}$ yang optimal. Selain itu, kendala pengembangan padi gogo di bawah tegakan tanaman karet adalah rendahnya intensitas cahaya karena faktor naungan tajuk tanaman karet. Hal ini karena secara umum jarak tanam karet yang digunakan adalah $6 \mathrm{~m} \times 3 \mathrm{~m}$ sehingga dapat ditanami padi gogo sebagai tanaman sela hanya sampai tanaman karet berumur 1-2 tahun (Rosyid et al., 2012; Pansak, 2015). Dengan jarak tanam karet tersebut ketika tanaman karet berumur $>2$ tahun, tajuk tanaman karet sudah saling menutup dengan pengurangan intensitas cahaya mencapai 5060\% (Pansak, 2015; Sahuri et al., 2016; Sahuri, 2017). Padi gogo yang ditanam di bawah naungan kurang dari $50 \%$ mengalami penurunan hasil mencapai 50-60\%, dibandingkan dengan keadaan tanpa naungan (Sopandie et al., 2002; Rosyid et al., 2012).

Rata-rata produktivitas padi gogo di Indonesia masih rendah yaitu 2,87 ton/ha atau $60 \%$ dari produktivitas padi sawah yang mencapai 4,74 ton/ha (Badan Pusat Statistik, 2015). Hasil padi gogo dengan sistem tumpang sari karet masih rendah yaitu 2-3 ton/ha GKG dibandingkan secara monokultur yang dapat mencapai 4-5 ton/ha gabah kering giling (GKG) (Toha, 2005). Rendahnya hasil tersebut disebabkan belum menggunakan varietas unggul dan teknik pemupukan yang tidak tepat (Putra, 2012). Penggunaan varietas unggul dan pemberian pupuk $90 \mathrm{~kg} \mathrm{~N} / \mathrm{ha}$ merupakan perlakuan terbaik pada penelitian pemupukan NPK padi gogo sebagai tanaman sela karet muda. Hal ini karena mampu mencapai hasil > 3,0 ton/ha sehingga dapat mempercepat kenaikan hasil dan pendapatan petani (Pirngadi et al., 2007).

Unsur hara yang penting dan harus tersedia untuk budidaya padi gogo di lahan kering adalah N, P, dan K. Pemberian 45, 90, dan 135 $\mathrm{kg} \mathrm{N} /$ ha nyata meningkatkan pertumbuhan dan hasil padi gogo varietas Situ Bagendit, Situ Patenggang, dan Batutegi di dataran sedang (Alavan et al., 2015). Pemupukan dengan dosis $90 \mathrm{~kg} \mathrm{~N} / \mathrm{ha}+36 \mathrm{~kg} \mathrm{P}_{2} \mathrm{O}_{5} / \mathrm{ha}+60 \mathrm{~kg} \mathrm{~K}_{2} \mathrm{O} / \mathrm{ha}$ nyata meningkatkan hasil padi gogo varietas Cirata, Way Rarem, dan Jatiluhur hingga 91\% dari $2,89 \mathrm{t} /$ ha menjadi $5,52 \mathrm{t} /$ ha yang ditanam secara monokulutur dilahan kering (Suwarno et al., 2004). Takaran pupuk yang optimal untuk padi gogo adalah $90 \mathrm{~kg} \mathrm{~N} / \mathrm{ha}$ atau setara $200 \mathrm{~kg}$ Urea/ha. Pemberian pupuk N yang tinggi akan meningkatkan serangan penyakit blas sehingga hasil padi gogo akan menurun (Santika \& Sunaryo, 2008).

Pada dasarnya penelitian mengenai formulasi dosis pemupukkan yang tepat untuk padi gogo yang ditanam secara monokultur di lahan kering sudah banyak dilakukan. Namun, formulasi dosis pupuk perlu dilakukan pada padi gogo sebagai tanaman sela karet dan melihat pengaruhnya terhadap pertumbuhan karet klon PB 340. Hal ini karena setiap varietas padi gogo dan formulasi pupuk yang digunakan harus spesifik lokasi, hubungannya dengan pasokan hara yang spesifik. Areal karet klon PB 340 dipilih dalam penelitian ini karena berdasarkan hasil survei lokasi penelitian menunjukkan bahwa areal tanaman karet klon PB 340 berumur 18 bulan setelah tanam (BST) dengan intensitas cahaya di bawah tegakan karet sebesar 70-75\% diukur menggunakan menggunakan alat LI-COR Line Quantum Sensor. Hal ini menunjukkan bahwa lokasi areal klon PB 340 sesuai untuk penelitian pola tumpangsari padi gogo. Oleh karena itu, penelitian ini bertujuan mengetahui pengaruh tumpangsari padi gogo terhadap pertumbuhan karet klon PB 340 dan mendapatkan paket pemupukan NPK padi gogo sebagai tanaman sela karet. 


\section{Bahan dan Metode}

Penelitian dilaksanakan di Kebun Percobaan Balai Penelitian Sembawa pada musim hujan (MH 2016/2017) dari bulan November 2016 sampai Maret 2017. Lokasi penelitian dipilih pada areal kebun karet klon PB 340 berjarak tanam $6 \mathrm{~m} \times 3 \mathrm{~m}$ (550 pohon/ha). Tanaman karet tersebut berumur 18 bulan setelah tanam (BST) yang cukup seragam berdasarkan pada jenis klon karet dan keragaan pertanaman. Intensitas cahaya di bawah tegakan karet adalah $70-75 \%$ diukur menggunakan menggunakan alat LI-COR Line Quantum Sensor.

Penelitian menggunakan rancangan petak terpisah dengan 3 ulangan. Sebagai petak utama adalah kombinasi pupuk $\mathrm{P}$ dan $\mathrm{K}$ dengan empat perlakuan yaitu: (1) $0 \mathrm{~kg}$ $\mathrm{P}_{2} \mathrm{O}_{5} / \mathrm{ha}+0 \mathrm{~kg} \mathrm{~K} 2 \mathrm{O} / \mathrm{ha}$, (2) $36 \mathrm{~kg} \mathrm{P}_{2} \mathrm{O}_{5} / \mathrm{ha}+0$ $\mathrm{kg} \mathrm{K}_{2} \mathrm{O} / \mathrm{ha}$, (3) $0 \mathrm{~kg} \mathrm{P}_{2} \mathrm{O}_{5} / \mathrm{ha}+60 \mathrm{~kg} \mathrm{~K}_{2} \mathrm{O} / \mathrm{ha}$, dan (4) $36 \mathrm{~kg} \mathrm{P}_{2} \mathrm{O}_{5} / \mathrm{ha}+60 \mathrm{~kg} \mathrm{~K}_{2} \mathrm{O} / \mathrm{ha}$. Sebagai anak petak adalah pemberian pupuk $\mathrm{N}(0,45$, $90,135) \mathrm{kg} \mathrm{N} / \mathrm{ha}$. Ukuran tiap plot percobaan adalah $4 \mathrm{~m} \times 5 \mathrm{~m}$ sebanyak 48 plot dengan jarak antara plot $1 \mathrm{~m}$ dan jarak plot dari tanaman karet $1 \mathrm{~m}$. Varietas yang digunakan adalah Situ Bagendit dengan jarak tanam $40 \times 10 \mathrm{~cm}, 4-5$ butir per lubang. Pemupukan N, $1 / 2$ dosis diberikan pada umur 14 hari setelah tanam (HST) bersama dengan $\mathrm{P}$ dan $\mathrm{K}$ serta sisanya pupuk $\mathrm{N}$ diberikan pada saat primordia bunga. Pemberian pupuk $\mathrm{N}$ pertama bersama pupuk $\mathrm{P}$ dan $\mathrm{K}$ dilakukan dengan cara dilarik dan ditutup lagi dengan tanah setelah diberikan. Pemberian pupuk $\mathrm{N}$ kedua dilakukan dengan disebar merata. Penyiangan dilakukan pada umur 14 HST dan 28 HST. Pengendalian hama penyakit sesuai anjuran.

Data yang diamati yaitu curah hujan, analisis tanah sebelum dan sesudah tanam, lilit batang karet $100 \mathrm{~cm}$ dari pertautan okulasi (dpo) sebelum dan sesudah penanaman padi gogo, tinggi tanaman padi gogo, jumlah anakan, bobot 1000 biji, dan hasil gabah kering giling (GKG) dengan kadar air 14\%. Data dianalisis dengan sidik ragam, jika berbeda nyata maka dilanjutkan dengan uji DMRT pada taraf $5 \%$ dengan program SAS 9.0. Data pertumbuhan lilit batang tanaman karet dianalisis menggunakan uji t (paired samples test) dengan membandingkan pertumbuhan lilit batang karet pola tumpang sari padi gogo dengan pola karet monokultur (Gomez \& Gomes, 1995).

\section{Hasil dan Pembahasan}

\section{Karakteristik Lahan}

Jenis tanah pada lokasi penelitian adalah ultisol dengan tofografi mendatar dan tekstur lempung liat berpasir. Hasil analisis tanah sebelum tanam menunjukkan bahwa nilai $\mathrm{pH}$ dan kadar unsur hara sangat rendah, sedangkan saat panen nilai $\mathrm{pH}$ tanah dan kadar unsur hara meningkat dari sangat rendah menjadi sedang sampai tinggi. Hal ini menunjukkan bahwa adanya budidaya padi gogo sebagai tanaman sela karet berpengaruh positif terhadap peningkatan daya dukung lahan. Namun, tanah tersebut memiliki kejenuhan alumunium (Al) yang tinggi 50,60\% (Tabel 1). Kondisi tanah yang demikian tergolong lahan bermasalah dan mempunyai tingkat kesuburan yang rendah. Menurut Santika (2011), batas kritis kejenuhan Al untuk padi gogo adalah sekitar 40\%. Menurut Prasetyo \& Suriadikarta (2006) ketersediaan hara $\mathrm{N}, \mathrm{P}, \mathrm{K}, \mathrm{Ca}$, dan $\mathrm{Mg}$ dipengaruhi oleh $\mathrm{pH}$ tanah dan jumlah Al bebas dalam tanah. Kandungan Al tinggi di dalam tanah menyebabkan kation-kation terutama $\mathrm{P}$ terikat menjadi Al-P yang sulit untuk dilepas, sehingga $P$ tidak tersedia bagi tanaman.

Rata-rata curah hujan 10 Tahun (20072017) tercantum pada Tabel 1. Jumlah curah hujan dilokasi penelitian adalah 2500-3000 $\mathrm{mm} /$ tahun. Curah hujan tertinggi terjadi pada bulan November - Mei (200-300 mm) dan bulan-bulan kering terjadi pada bulan Juni September (70-100 mm). Rata-rata kelembaban udara sepanjang tahun $>80 \%$ dengan rata-rata suhu udara maksimum $32{ }^{\circ} \mathrm{C}$ dan minimum $23^{\circ} \mathrm{C}$ (stasiun klimatologi Balai Penelitian Sembawa, Pusat Penelitian Karet). Berdasarkan sebaran bulan basah dan bulan kering tersebut, maka kecukupan air tidak menjadi faktor pembatas bagi pengembangan padi gogo sebagai tanaman sela karet di wilayah tersebut. 
Tabel 1. Analisis tanah sebelum dan sesudah tanam serta rata-rata curah hujan setiap bulan selama 10 tahun (2007-2017) di KP. Balai Penelitian Sembawa.

\begin{tabular}{lcclc}
\hline \multicolumn{1}{c}{ Peubah Analisis } & Sebelum & Saat Panen & Bulan & Curah Hujan (mm) \\
\hline $\mathrm{pH}$ & $4,37 \mathrm{sm}$ & $5,04 \mathrm{~m}$ & Januari & 284 \\
$\mathrm{C}$ - Organik (\%) & $1,83 \mathrm{r}$ & $3,19 \mathrm{t}$ & Februari & 277 \\
$\mathrm{~N}$-total (\%) & $0,13 \mathrm{r}$ & $0,20 \mathrm{sd}$ & Maret & 321 \\
$\mathrm{P}_{2} \mathrm{O}_{5}$ (Bray II) (ppm) & $4,77 \mathrm{sr}$ & $5,19 \mathrm{r}$ & April & 357 \\
$\mathrm{~K}_{2} \mathrm{O}$ (Morgan) (me/100 gr) & $0,02 \mathrm{sr}$ & $0,05 \mathrm{sr}$ & Mei & 135 \\
$\mathrm{Ca}$ (me/100 gr) & $0,11 \mathrm{sr}$ & $0,20 \mathrm{sr}$ & Juni & 110 \\
$\mathrm{Mg}$ (me/100 gr) & $0,02 \mathrm{sr}$ & $0,12 \mathrm{r}$ & Juli & 82 \\
$\mathrm{KTK}$ (me/100 gr) & $8,9 \mathrm{sr}$ & $10,74 \mathrm{r}$ & Agustus & 75 \\
$\mathrm{Kejenuhan} \mathrm{Al}$ & $50,60 \mathrm{st}$ & & September & 74 \\
Pasir (Sand) & 46,67 & & Oktober & 209 \\
Debu (Dust) & 25,83 & & Nopember & 306 \\
Liat (Clay) & 26.49 & & Desember & 341 \\
\hline
\end{tabular}

Keterangan: $\mathrm{r}=$ rendah; $\mathrm{sr}=$ sangat rendah; $\mathrm{sd}=$ sedang; $\mathrm{t}=$ tinggi; $\mathrm{st}=$ sangat tinggi; $\mathrm{m}=$ masam; $\mathrm{sm}=$ sangat masam; kriteria iklim Schmidt-Ferguson (bulan kering $<60 \mathrm{~mm}$ dan bulan basah $>100$ $\mathrm{mm}$ )

\section{Lilit Batang Karet}

Pertumbuhan lilit batang karet klon PB 340 pada umur 18 BST, sebelum penanaman padi gogo cukup seragam dengan rata-rata 16,25 $\mathrm{cm}$ dan tidak berbeda nyata $(\mathrm{P}>0,05)$. Namun pertumbuhan lilit batang karet pada umur 24
BST setelah penanaman padi gogo cenderung lebih tinggi meningkat $36,26 \%$ dibandingkan dengan tanaman karet monokultur yang hanya meningkat $25,74 \%$ dan berbeda nyata $(\mathrm{P}<0,05)($ Tabel 2).

Tabel 2. Lilit batang karet pada pola tanam padi gogo sebagai tanaman sela karet

\begin{tabular}{lccc}
\hline \multirow{2}{*}{ Perlakuan } & \multicolumn{2}{c}{ Lilit Batang $(\mathrm{cm})$} & Kenaikan \\
\cline { 2 - 3 } & 18 BST & 24 BST & $(\%)$ \\
\hline Karet Monokultur & $16,20 \mathrm{a}$ & $20,37 \mathrm{~b}$ & 25,74 \\
Karet Pola Tumpangsari Padi & $16,30 \mathrm{a}$ & $22,21 \mathrm{a}$ & 36,26 \\
P & $0,48^{\text {tn }}$ & $0,032^{*}$ & \\
\hline
\end{tabular}

Keterangan:

$\checkmark \quad{ }^{*}$ ) nyata padaP $<0.05 \mathrm{dan}^{\mathrm{tn}}$ ) tidak berbeda nyata

$\checkmark \quad$ lilit batang karet umur 18 bulan setelah tanam(BST) sebelum penanaman padi gogo

$\checkmark \quad$ lilit batang karet umur 24 BST setelah penanaman padi gogo.

Pertumbuhan tanaman karet dengan adanya tanaman sela padi gogo tidak mengalami kelambatan, bahkan tumbuh lebih baik dibandingkan dengan tanaman karet monokultur. Hasil penelitian (Rodrigo et al., 2004; Rodrigo et al., 2005; Sahuri \& Rosyid, 2015; Xianhai et al., 2012) menunjukkan bahwa pertumbuhan karet pada masa TBM dipengaruhi oleh adanya tanaman sela. Tanaman sela berpengaruh pada peningkatan pertumbuhan karet, ketebalan kulit, hasil lateks, dan mempersingkat masa TBM dibandingkan dengan tanaman karet monokultur.

Pertumbuhan tanaman karet juga dipengaruhi oleh sistem pengolahan tanah padi gogo seperti pencangkulan, penggaruan, dan pembumbunan. Hal ini menyebabkan tanah gembur sehingga pertumbuhan dan perkembangan akar tanaman karetlebih baik. 
Hasil penelitian Wibawa \& Rosyid (1995), perbaikan struktur tanah ultisol melalui pengolahan tanah untuk tanaman sela padi gogo dapat meningkatkan serapan unsur hara $\mathrm{N}, \mathrm{P}$, dan $\mathrm{K}$ sehingga sistem perakaran menjadi lebih baik. Selanjutnya menurut Ar-riza et al. (2001) kegiatan pengolahan tanah dapat membentuk agregat tanah yang stabil sehingga perkembangan akar, pergerakan air, dan udara akan lebih mudah dan bebas.

\section{Pertumbuhan dan Produksi Padi Gogo Sebagai Tanaman Sela Karet}

\section{Tinggi Tanaman}

Kombinasi pupuk PK nyata meningkatkan tinggi tanaman padi gogo pada umur 6 MST dan 10 MST. Tanaman tertinggi pada umur 6
MST ditunjukkan oleh perlakuan $0 \mathrm{~kg}$ $\mathrm{P}_{2} \mathrm{O}_{5} / \mathrm{ha}+60 \mathrm{~kg} \mathrm{~K}$ O/ha sebesar 58,17 cm, berbeda nyata dengan perlakuan tanpa $\mathrm{PK}$ dan $36 \mathrm{~kg} \mathrm{P}_{2} \mathrm{O}_{5} / \mathrm{ha}+0 \mathrm{~kg} \mathrm{~K}{ }_{2} \mathrm{O} / \mathrm{ha}$, tetapi tidak berbeda nyata dengan perlakuan $36 \mathrm{~kg}$ $\mathrm{P}_{2} \mathrm{O}_{5} /$ ha ${ }_{+} 60 \mathrm{~kg} \mathrm{~K} \mathrm{O}_{2} /$ ha. Pada umur $10 \mathrm{MST}$ tanaman tertinggi pada perlakuan $36 \mathrm{~kg}$ $\mathrm{P}_{2} \mathrm{O}_{5} / \mathrm{ha}+0 \mathrm{~kg} \mathrm{~K} 2 \mathrm{O} /$ ha sebesar $64,12 \mathrm{~cm}$, berbeda nyata dengan perlakuan tanpa PK tetapi tidak berbeda nyata dengan perlakuan lainnya (Tabel 3). Hal ini menunjukkan bahwa pemberian pupuk $\mathrm{P}$ dan $\mathrm{K}$ masing-masing sebanyak $36 \mathrm{~kg} \mathrm{P}_{2} \mathrm{O}_{5} /$ ha dan $60 \mathrm{~kg} \mathrm{~K}_{2} \mathrm{O} / \mathrm{ha}$ meningkatkan pertumbuhan padi gogo. Adanya pemberian pupuk $\mathrm{P}$ dan $\mathrm{K}$ mempengaruhi tinggi tanaman. Hal ini sejalan dengan penelitian yang dilakukan oleh Pirngadi et al. (2012).

Tabel 3. Tinggi tanaman padi gogo sebagai tanaman sela karet pada perlakuan pupuk NPK

\begin{tabular}{ccccc}
\hline \multicolumn{2}{c}{ Kombinasi Pupuk (kg/ha) } & \multicolumn{2}{c}{ Tinggi Tanaman $(\mathrm{cm})$} \\
\hline $\mathrm{N}$ & $\mathrm{P}_{2} \mathrm{O}_{5}$ & $\mathrm{~K}_{2} \mathrm{O}$ & $6 \mathrm{MST}$ & $10 \mathrm{MST}$ \\
& 0 & 0 & $51,65 \mathrm{c}$ & $58,35 \mathrm{~b}$ \\
& 0 & 60 & $58,17 \mathrm{a}$ & $63,58 \mathrm{a}$ \\
& 36 & 0 & $54,60 \mathrm{bc}$ & $64,12 \mathrm{a}$ \\
& 36 & 60 & $57,36 \mathrm{ab}$ & $63,92 \mathrm{a}$ \\
0 & & $52,63 \mathrm{~b}$ & $58,83 \mathrm{c}$ \\
45 & & $55,58 \mathrm{ab}$ & $63,16 \mathrm{ab}$ \\
90 & & $56,67 \mathrm{a}$ & $66,73 \mathrm{a}$ \\
135 & & $56,90 \mathrm{a}$ & $61,23 \mathrm{bc}$ \\
$\mathrm{R}^{2}$ & & 0,72 & 0,71 \\
$\mathrm{KK}$ & & 6,44 & 7,52 \\
$\mathrm{P}<0,05$ & & $0,028^{*}$ & $0,003^{*}$ \\
\hline
\end{tabular}

Keterangan: angka yang diikuti dengan huruf yang sama pada kolom yang sama tidak berbeda nyata menurut uji DMRT $5 \%$.

Pemberian pupuk $\mathrm{N}$ nyata meningkatkan tinggi tanaman padi gogo pada umur 6 dan 10 MST. Pada umur 6 MST tanaman tertinggi pada perlakuan $135 \mathrm{~kg} \mathrm{~N} /$ ha sebesar $56,90 \mathrm{~cm}$ berbeda nyata dengan perlakuan tanpa pupuk $\mathrm{N}$, tetapi tidak berbeda nyata dengan perlakuan lainnya. Pada umur $10 \mathrm{MST}$ tanaman tertinggi pada perlakuan $90 \mathrm{~kg} \mathrm{~N} / \mathrm{ha}$ sebesar $66,73 \mathrm{~cm}$ berbeda nyata dengan perlakuan lainnya (Tabel 3). Hal ini menunjukkan bahwa pemberian pupuk $\mathrm{N}$ yang optimal untuk meningkatkan pertumbuhan padi gogo sebanyak $90 \mathrm{~kg} \mathrm{~N} / \mathrm{ha}$. Adanya pemberian pupuk $90 \mathrm{~kg} \mathrm{~N} /$ ha mempengaruhi tinggi tanaman yang optimal. Hal ini sejalan dengan penelitian Pirngadi et al. (2007) dan Santika \& Sunaryo (2008). 
Tabel 4. Interaksi kombinasi pupuk NP dan Kterhadap tinggi tanaman padi gogo

\begin{tabular}{ccccc}
\hline \multicolumn{2}{c}{ Kombinasi Pupuk $(\mathrm{kg} / \mathrm{ha})$} & \multicolumn{1}{c}{$6 \mathrm{MST}$} & \multicolumn{1}{c}{ MST } \\
\cline { 3 - 4 } $\mathrm{N}$ & $\mathrm{P}_{2} \mathrm{O}_{5}$ & $\mathrm{~K}_{2} \mathrm{O}$ & Tinggi Tanaman $(\mathrm{cm})$ & Tinggi Tanaman $(\mathrm{cm})$ \\
0 & & & $49,90 \mathrm{e}$ & $54,87 \mathrm{~d}$ \\
45 & & & $52,63 \mathrm{cde}$ & $59,40 \mathrm{bcd}$ \\
90 & & & $52,27 \mathrm{de}$ & $62,40 \mathrm{abcd}$ \\
135 & & & $51,80 \mathrm{de}$ & $56,73 \mathrm{~cd}$ \\
0 & 36 & & $53,00 \mathrm{bcde}$ & $61,47 \mathrm{abcd}$ \\
45 & 36 & & $53,93 \mathrm{abcde}$ & $65,00 \mathrm{abc}$ \\
90 & 36 & & $54,67 \mathrm{abcde}$ & $67,60 \mathrm{ab}$ \\
135 & 36 & & $56,80 \mathrm{abcde}$ & $62,40 \mathrm{abcd}$ \\
0 & & 60 & $54,53 \mathrm{abcde}$ & $61,73 \mathrm{abcd}$ \\
45 & & 60 & $60,67 \mathrm{ab}$ & $66,67 \mathrm{ab}$ \\
90 & & 60 & $60,27 \mathrm{abc}$ & $66,67 \mathrm{ab}$ \\
135 & & 60 & $57,20 \mathrm{abcde}$ & $59,27 \mathrm{bcd}$ \\
0 & 36 & 60 & $53,07 \mathrm{bcde}$ & $57,27 \mathrm{~cd}$ \\
45 & 36 & 60 & $55,10 \mathrm{abcde}$ & $61,60 \mathrm{abcd}$ \\
90 & 36 & 60 & $59,47 \mathrm{abcd}$ & $70,27 \mathrm{a}$ \\
135 & 36 & 60 & $61,80 \mathrm{a}$ & $66,53 \mathrm{ab}$ \\
$\mathrm{R}^{2}$ & & & 0,62 & 0,77 \\
$\mathrm{KK}$ & & & 7,31 & 7,61 \\
$\mathrm{P}<0,05$ & & & $0,025^{*}$ & $0,015^{*}$ \\
\hline
\end{tabular}

Keterangan: angka yang diikuti dengan huruf yang sama pada kolom yang sama tidak berbeda nyata menurut uji DMRT $5 \%$.

Interaksi kombinasi pupuk $\mathrm{PK}$ dan $\mathrm{N}$ nyata meningkatkan tinggi tanaman pada umur 6 MST dan 10 MST. Pada umur 6 MST tanaman tertinggi pada kombinasi pupuk 135 $\mathrm{kg} \mathrm{N} / \mathrm{ha}+36 \mathrm{~kg} \mathrm{P}_{2} \mathrm{O}_{5} / \mathrm{ha}+60 \mathrm{~kg} \mathrm{~K} \mathrm{O}_{2} / \mathrm{ha}$ sebesar $61,80 \mathrm{~cm}$, sedangkan pada umur 10 MST tanaman tertinggi pada kombinasi pupuk $90 \mathrm{~kg} \mathrm{~N} / \mathrm{ha}+36 \mathrm{~kg} \mathrm{P}_{2} \mathrm{O}_{5} / \mathrm{ha}+60 \mathrm{~kg}$ $\mathrm{K}_{2} \mathrm{O} /$ ha sebesar $70,27 \mathrm{~cm}$ (Tabel 4). Hasil tersebut berbeda nyata dengan perlakuan kombinasi pupuk PK dan N lainnya. Hal ini menunjukkan bahwa kombinasi pupuk $\mathrm{N}, \mathrm{P}$, dan $\mathrm{K}$ yang optimal untuk meningkatkan tinggi tanaman padi gogo masing-masing sebanyak $90 \mathrm{~kg} \mathrm{~N} / \mathrm{ha}, 36 \mathrm{~kg} \mathrm{P}_{2} \mathrm{O}_{5} / \mathrm{ha}$, dan $60 \mathrm{~kg}$ $\mathrm{K}_{2} \mathrm{O} /$ ha. Hasil penelitian Kasniari \& Supadma (2007) interaksi antara perlakuan dosis pupuk $(\mathrm{N}, \mathrm{P}, \mathrm{K})$ tidak berpengaruh nyata $(\mathrm{P}>0,05)$ terhadap tinggi tanaman padi gogo. Namun berpengaruh nyata $(\mathrm{P}<0,05)$ terhadap jumlah anakan padi gogo dan terdapat interaksi yang nyata kombinasi pupuk PK dan $\mathrm{N}$ terhadap tinggi tanaman padi gogo pada umur 4, 5, dan $6 \mathrm{MST}$.

\section{Jumlah Anakan}

Kombinasi pupuk PK nyata meningkatkan jumlah anakan padi gogo pada umur 6 MST dan 10 MST. Pada umur 6 MST jumlah anakan tertinggi pada perlakuan $36 \mathrm{~kg} \mathrm{P}_{2} \mathrm{O}_{5} / \mathrm{ha}{ }_{+} 60 \mathrm{~kg}$ $\mathrm{K}_{2} \mathrm{O} /$ ha sebesar $12,23 \mathrm{~cm}$, berbeda nyata dengan perlakuan lainnya. Pada umur 10 MST jumlah anakan tertinggi pada perlakuan $36 \mathrm{~kg}$ $\mathrm{P}_{2} \mathrm{O}_{5} / \mathrm{ha}+60 \mathrm{~kg} \mathrm{~K} \mathrm{O}_{2} /$ ha sebesar $12,47 \mathrm{~cm}$, berbeda nyata dengan perlakuan lainnya (Tabel 5). Hal ini menunjukkan bahwa pemberian pupuk $\mathrm{P}$ dan $\mathrm{K}$ untuk meningkatkan jumlah anakan padi gogo masing-masing sebanyak $36 \mathrm{~kg} \mathrm{P}_{2} \mathrm{O}_{5} /$ ha dan 60 $\mathrm{kg} \mathrm{K}_{2} \mathrm{O} /$ ha. Adanya pemberian pupuk $\mathrm{P}$ dan $\mathrm{K}$ mempengaruhi jumlah anakan, hal ini sejalan dengan penelitian Santika (2011). 
Tabel 5. Jumlah anakan padi gogo sebagai tanaman sela karet pada perlakuan pupuk NPK

\begin{tabular}{ccccc}
\hline \multicolumn{4}{c}{ Kombinasi Pupuk (kg/ha) } & \multicolumn{2}{c}{ Jumlah Anakan } \\
\hline \multicolumn{1}{c}{$\mathrm{N}$} & $\mathrm{P}_{2} \mathrm{O}_{5}$ & $\mathrm{~K}_{2} \mathrm{O}$ & $6 \mathrm{MST}$ & $10 \mathrm{MST}$ \\
& 0 & 0 & $11,08 \mathrm{c}$ & $11,50 \mathrm{c}$ \\
& 0 & 60 & $11,62 \mathrm{~b}$ & $11,94 \mathrm{~b}$ \\
& 36 & 0 & $11,53 \mathrm{~b}$ & $12,05 \mathrm{~b}$ \\
& 36 & 60 & $12,23 \mathrm{a}$ & $12,65 \mathrm{a}$ \\
& & $10,75 \mathrm{c}$ & $11,07 \mathrm{c}$ \\
0 & & $11,63 \mathrm{~b}$ & $12,12 \mathrm{~b}$ \\
45 & & $12,37 \mathrm{a}$ & $12,89 \mathrm{a}$ \\
90 & & $11,72 \mathrm{~b}$ & $12,06 \mathrm{~b}$ \\
135 & & 0,86 & 0,89 \\
$\mathrm{R}^{2}$ & & 4,19 & 3,74 \\
$\mathrm{KK}$ & & $<.0001$ & $<.0001$ \\
$\mathrm{P}<0,05$ & & &
\end{tabular}

Keterangan: angka yang diikuti dengan huruf yang sama pada kolom yang sama tidak berbeda nyata menurut uji DMRT $5 \%$.

Tabel 6. Interaksi pupuk N, P, dan Kterhadap jumlah anakan sebagai tanaman sela karet

\begin{tabular}{ccccc}
\hline \multicolumn{2}{c}{ Kombinasi Pupuk $(\mathrm{kg} / \mathrm{ha})$} & \multicolumn{1}{c}{$6 \mathrm{MST}$} & \multicolumn{1}{c}{$10 \mathrm{MST}$} \\
\hline $\mathrm{N}$ & $\mathrm{P}_{2} \mathrm{O}_{5}$ & $\mathrm{~K}_{2} \mathrm{O}$ & Jumlah Anakan & Jumlah Anakan \\
\hline 0 & & & $10,40 \mathrm{~g}$ & $11,30 \mathrm{f}$ \\
45 & & & $10,87 \mathrm{fgh}$ & $12,07 \mathrm{cde}$ \\
90 & & & $11,73 \mathrm{cdef}$ & $11,80 \mathrm{cdef}$ \\
135 & & & $11,33 \mathrm{defgh}$ & $11,00 \mathrm{f}$ \\
0 & 36 & & $10,67 \mathrm{gh}$ & $12,20 \mathrm{~cd}$ \\
45 & 36 & & $11,47 \mathrm{cdefg}$ & $13,50 \mathrm{ab}$ \\
90 & 36 & & $12,87 \mathrm{ab}$ & $11,50 \mathrm{def}$ \\
135 & 36 & & $11,13 \mathrm{defgh}$ & $11,07 \mathrm{ef}$ \\
0 & & 60 & $10,87 \mathrm{fgh}$ & $12,37 \mathrm{~cd}$ \\
45 & & 60 & $12,07 \mathrm{bcde}$ & $12,20 \mathrm{~cd}$ \\
90 & & 60 & $11,60 \mathrm{cdefg}$ & $12,13 \mathrm{~cd}$ \\
135 & & 60 & $11,93 \mathrm{bcde}$ & $11,40 \mathrm{def}$ \\
0 & 36 & 60 & $11,07 \mathrm{efgh}$ & $12,60 \mathrm{bc}$ \\
45 & 36 & 60 & $12,13 \mathrm{bcd}$ & $13,80 \mathrm{a}$ \\
90 & 36 & 60 & $13,27 \mathrm{a}$ & $12,80 \mathrm{bc}$ \\
135 & 36 & 60 & $12,47 \mathrm{abc}$ & 0,8 \\
$\mathrm{R}^{2}$ & & & 0,77 & 4,53 \\
$\mathrm{KK}$ & & & 4,72 & $<.0001^{*}$ \\
$\mathrm{P}<0,05$ & & & $<.0001^{*}$ & \\
\hline
\end{tabular}

Keterangan: angka yang diikuti dengan huruf yang sama pada kolom yang sama tidak berbeda nyata menurut uji DMRT $5 \%$.

Pemberian pupuk $\mathrm{N}$ nyata meningkatkan jumlah anakan padi gogo pada umur 6 MST dan 10 MST. Pada umur 6 MST jumlah anakan tertinggi pada perlakuan $90 \mathrm{~kg} \mathrm{~N} /$ ha sebesar 12,37 berbeda nyata dengan perlakuan lainnya. Pada umur 10 MST jumlah anakan tertinggi pada perlakuan $90 \mathrm{~kg} \mathrm{~N} /$ ha sebesar 12,89 berbeda nyata dengan perlakuan lainnya (Tabel 5). Hal ini menunjukkan bahwa pemberian pupuk $\mathrm{N}$ yang optimal untuk meningkatkan jumlah anakan padi gogo sebanyak $90 \mathrm{~kg} \mathrm{~N} /$ ha. 
Interaksi kombinasi pupuk $\mathrm{PK}$ dan $\mathrm{N}$ nyata meningkatkan jumlah anakan pada umur 6 MST dan 10 MST. Pada umur 6 MST dan 10 MST tanaman tertinggi pada kombinasi pupuk $90 \mathrm{~kg} \mathrm{~N} / \mathrm{ha}+36 \mathrm{~kg} \mathrm{P}_{2} \mathrm{O}_{5} / \mathrm{ha}+60 \mathrm{~kg} \mathrm{~K} \mathrm{O} / \mathrm{ha}$ masing-masing sebesar 13,27 anakan dan 13,80 anakan (Tabel 6). Hasil tersebut berbeda nyata dengan perlakuan kombinasi pupuk PK dan $\mathrm{N}$ lainnya. Hal ini menunjukkan bahwa kombinasi pupuk $\mathrm{N}, \mathrm{P}$, dan $\mathrm{K}$ yang optimal untuk meningkatkan jumlah anakan padi gogo masing-masing sebanyak $90 \mathrm{~kg} \mathrm{~N} / \mathrm{ha}, 36 \mathrm{~kg}$ $\mathrm{P}_{2} \mathrm{O}_{5} /$ ha, dan $60 \mathrm{~kg} \mathrm{~K} \mathrm{O}_{2} / \mathrm{ha}$. Hasil penelitian Kasniari \& Supadma (2007) interaksi antara perlakuan dosis pupuk $(\mathrm{N}, \mathrm{P}, \mathrm{K})$ berrpengaruh nyata $(\mathrm{P}<0,05)$ terhadap jumlah anakan padi gogo. Selanjutnya Alavan et al. (2015) menyatakan bahwa terdapat interaksi yang nyata kombinasi pupuk PK dan $\mathrm{N}$ terhadap jumlah anakan padi gogo pada umur 4, 5, dan $6 \mathrm{MST}$.

\section{Bobot 1000 Biji}

Kombinasi pupuk $\mathrm{P}$ dan $\mathrm{K}$ tidak nyata meningkatkan bobot 1000 biji padi gogo, namun bobot 1000 biji tertinggi dicapai pada perlakuan $36 \mathrm{P}_{2} \mathrm{O}_{5} \mathrm{~kg} / \mathrm{ha}+60 \mathrm{~K}_{2} \mathrm{O} \mathrm{kg} / \mathrm{ha}$ sebesar 26,65 g. Pemberian pupuk $\mathrm{N}$ juga tidak nyata meningkatkan bobot 1000 biji, namun bobot 1000 biji tertinggi dicapai pada perlakuan $90 \mathrm{~N} \mathrm{~kg}$ /ha sebesar 26,68 g. (Tabel 7). Bobot 1000 biiji lebih dipengaruhi oleh faktor genetis. Adanya pemberian pupukpupuk tidak mempengaruhi bobot 1000 biji sejalan dengan penelitian Pirngadi et al. (2012).

Tabel 7.Bobot 1000 biji padi gogo sebagai tanaman sela karet pada perlakuan pupuk NPK

\begin{tabular}{cccc}
\hline \multicolumn{2}{c}{ Kombinasi Pupuk (kg/ha) } & Bobot 1000 biji $(\mathrm{g})$ \\
\hline $\mathrm{N}$ & $\mathrm{P}_{2} 0_{5}$ & $\mathrm{~K}_{2} 0$ & $26,59 \mathrm{a}$ \\
& 0 & 0 & $26,60 \mathrm{a}$ \\
& 36 & 0 & $26,62 \mathrm{a}$ \\
& 0 & 60 & $26,65 \mathrm{a}$ \\
0 & 36 & 60 & $26,57 \mathrm{a}$ \\
45 & & & $26,63 \mathrm{a}$ \\
90 & & $26,68 \mathrm{a}$ \\
135 & & $26,59 \mathrm{a}$ \\
& $\mathrm{R}^{2}$ & & 0,62 \\
& $\mathrm{KK}$ & 0,30 \\
& $\mathrm{P}<0,05$ & & $0,32^{\text {th }}$ \\
\hline
\end{tabular}

Keterangan: angka yang diikuti dengan huruf yang sama pada kolom yang sama tidak berbeda nyata menurut uji DMRT $5 \%$.

\section{Hasil Gabah Kering}

Kombinasi pupuk $\mathrm{P}$ dan $\mathrm{K}$ tidak berpengaruh nyata pada peningkatan hasil gabah kering. Pupuk $\mathrm{P}$ dan $\mathrm{K}$ diberikan masing-masing $36 \mathrm{~kg} \mathrm{P}_{2} \mathrm{O}_{5} /$ ha dan $60 \mathrm{~kg}$ $\mathrm{K}_{2} \mathrm{O} /$ ha. Berdasarkan hasil analisis tanah pada Tabel 1, terlihat kadar P sangat rendah disertai $\mathrm{pH}$ tanah sangat masam dan kejenuhan $\mathrm{Al}$ yang tinggi. Pada kondisi ini menurut Notohadiprawiro (2006), Prasetyo \& Suriadikarta (2006) dan Santoso (2006) unsur $\mathrm{P}$ lebih banyak difiksasi oleh $\mathrm{Al}$ dan $\mathrm{Fe}$, sehingga unsur $\mathrm{P}$ tidak tersedia bagi tanaman.

Pupuk K diberikan $60 \mathrm{~kg} \mathrm{~K}_{2} \mathrm{O} /$ ha, dari hasil analisis tanah kadar $\mathrm{K}$ termasuk sedang. Adanya pemberian kedua pupuk $\mathrm{P}$ dan $\mathrm{K}$ tidak 
Tabel 8. Hasil gabah kering padi gogo sebagai tanaman sela karet pada perlakuan pupuk NPK

\begin{tabular}{ccccc}
\hline \multicolumn{2}{c}{ Kombinasi Pupuk (kg/ha) } & Hasil gabah kering (k.a 14\%) & Kenaikan Hasil (\%) \\
\cline { 1 - 2 } $\mathrm{N}$ & $\mathrm{P}_{2} \mathrm{O}_{5}$ & $\mathrm{~K}_{2} \mathrm{O}$ & & \\
\hline & 0 & 0 & $1,96 \mathrm{~h})$ & 6,12 \\
& 36 & 0 & $2,08 \mathrm{ab}$ & 14,29 \\
& 0 & 60 & $2,24 \mathrm{a}$ & 8,67 \\
0 & 36 & 60 & $2,13 \mathrm{ab}$ & 19,65 \\
45 & & $1,73 \mathrm{c}$ & 39,31 \\
90 & & $2,07 \mathrm{~b}$ & 26,58 \\
135 & & $2,41 \mathrm{a}$ & \\
$\mathrm{R}^{2}$ & & $2,19 \mathrm{~b}$ & \\
$\mathrm{KK}$ & & 0,81 & \\
$\mathrm{P}<0,05(\mathrm{PK})$ & & 9,73 & \\
\hline
\end{tabular}

Keterangan: angka yang diikuti dengan huruf yang sama pada kolom yang sama tidak berbeda nyata menurut uji DMRT $5 \%$.

Tabe1 9. Interaksi pupuk N, P, dan $\mathrm{K}$ terhadap hasil gabah kering padi gogo sebagai tanaman sela karet

\begin{tabular}{|c|c|c|c|c|}
\hline \multicolumn{3}{|c|}{ Kombinasi Pupuk (kg/ha) } & \multirow{2}{*}{$\begin{array}{c}\text { Hasil gabah kering } \\
\text { (k.a } 14 \%) \mathrm{kg} / \mathrm{ha})\end{array}$} & \multirow{2}{*}{$\begin{array}{c}\text { Kenaikan Hasil } \\
(\%)\end{array}$} \\
\hline $\mathrm{N}$ & $\mathrm{P}_{2} \mathrm{O}_{5}$ & $\mathrm{~K}_{2} \mathrm{O}$ & & \\
\hline 0 & & & $1,59 \mathrm{~d}$ & \\
\hline 45 & & & $1,70 \mathrm{~d}$ & 6,92 \\
\hline 90 & & & $2,37 a b$ & 49,06 \\
\hline 135 & & & $2,18 \mathrm{bc}$ & 37,11 \\
\hline 0 & 36 & & $1,80 \mathrm{dc}$ & 13,21 \\
\hline 45 & 36 & & $2,11 b c$ & 32,70 \\
\hline 90 & 36 & & $2,28 \mathrm{ab}$ & 43,40 \\
\hline 135 & 36 & & $2,14 \mathrm{bc}$ & 34,59 \\
\hline 0 & & 60 & $1,70 \mathrm{~d}$ & 6,92 \\
\hline 45 & & 60 & $2,36 a b$ & 48,43 \\
\hline 90 & & 60 & $2,60 a$ & 63,52 \\
\hline 135 & & 60 & $2,30 \mathrm{ab}$ & 44,65 \\
\hline 0 & 36 & 60 & $1,82 \mathrm{dc}$ & 14,47 \\
\hline 45 & 36 & 60 & $2,11 b c$ & 32,70 \\
\hline 90 & 36 & 60 & $2,40 a b$ & 50,94 \\
\hline 135 & 36 & 60 & $2,18 b c$ & 37,11 \\
\hline $\mathrm{R}^{2}$ & & & 0,75 & \\
\hline $\mathrm{KK}$ & & & 10.02 & \\
\hline $\mathrm{P}<0,05$ & & & $<.0001$ & \\
\hline
\end{tabular}

Keterangan: angka yang diikuti dengan huruf yang sama pada kolom yang sama tidak berbeda nyata menurut uji DMRT $5 \%$. 
nyata meningkatkan hasil. Namun, terlihat hasil gabah kering nyata tertinggi sebesar 2,24 ton/ha dicapai pada perlakuan $0 \mathrm{~kg} \mathrm{P}_{2} \mathrm{O}_{5} / \mathrm{ha}+$ $60 \mathrm{~kg} \mathrm{~K} \mathrm{~K}_{2} \mathrm{O} / \mathrm{ha}$ dengan kenaikan hasil 14,29\% (Tabel 7) dibanding tanpa PK. Hal ini menunjukkan bahwa $\mathrm{K}$ lebih berperan daripada P. Hal ini juga sejalan dengan hasil penelitian Pirngadu et al. (2012) yang menunjukkan bahwa unsur $\mathrm{K}$ lebih berperan dalam meningkatkan hasil padi gogo dibandingkan dengan unsur $\mathrm{P}$ dan $\mathrm{N}$.

Pemberian pupuk $\mathrm{N}$ meningkatkan hasil gabah kering dan berbeda nyata dibanding tanpa pupuk N. Perolehan hasil gabah kering tertinggi sebesar 2,41 ton/ha dicapai pada perlakuan $90 \mathrm{~kg} \mathrm{~N} /$ ha dengan kenaikan hasil $39,31 \%$ dibanding tanpa pupuk $\mathrm{N}$, tidak berbeda nyata dengan perlakuan $45 \mathrm{~kg} \mathrm{~N} / \mathrm{ha}$ dan $135 \mathrm{~kg} \mathrm{~N} / \mathrm{ha}$ (Tabel 8). Terlihat pemberian $\mathrm{N}$ di atas takaran $90 \mathrm{~kg} \mathrm{~N} / \mathrm{ha}$, hasil gabah kering menurun. Menurut Santika \& Sunaryo (2008) pemberian pupuk $\mathrm{N}$ yang tinggi akan meningkatkan serangan penyakit blas sehingga hasil padi gogo menurun.

Terdapat interaksi yang nyata $(\mathrm{P}<0,05)$ kombinasi pupuk PK dan $\mathrm{N}$ terhadap hasil gabah kering. Hasil gabah kering tertinggi pada kombinasi pupuk $90 \mathrm{~kg} \mathrm{~N} / \mathrm{ha}+0 \mathrm{~kg}$ $\mathrm{P}_{2} \mathrm{O}_{5} / \mathrm{ha}+60 \mathrm{~kg} \mathrm{~K} 2 \mathrm{O} /$ ha sebesar 2,60 ton/ha dengan kenaikan hasil 63,52\% dibanding tanpa kombinasi pupuk PK dan N (Tabel 9). Hasil tersebut berbeda nyata dengan perlakuan kombinasi pupuk PK dan $\mathrm{N}$ lainnya. Hal ini menunjukkan bahwa pupuk $\mathrm{N}$ dan $\mathrm{K}$ lebih berperan daripada $P$ untuk meningkatkan hasil gabah kering padi gogo.

\section{Kesimpulan}

Kombinasi pupuk N, P, dan K yang optimal untuk meningkatkan pertumbuhan dan hasil padi gogo sebagai tanaman sela karet adalah $90 \mathrm{~kg} \mathrm{~N} / \mathrm{ha}, 36 \mathrm{~kg} \mathrm{P}_{2} \mathrm{O}_{5} / \mathrm{ha}$, dan $60 \mathrm{~kg} \mathrm{~K}_{2} \mathrm{O} / \mathrm{ha}$. Pertumbuhan karet klon PB 340 dengan adanya tanaman sela padi gogo tidak mengalami kelambatan pertumbuhan, bahkan tumbuh lebih baik daripada pola monokultur.

\section{Daftar Pustaka}

Alavan, A., Hayati, R., \& Hayati, E. (2015). Pengaruh pemupukan terhadap pertumbuhan beberapa varietas padi gogo (Oryza sativa L.). Jurnal Floratek, 10(1), 61-68.

Ar-riza, I. D., Nazemi, \& Alwi. (2001, 17-19 Juli 2001). Peranan glifosat dalam pengendalian gulma dan suksesi gulma pada pertanaman padi intercrop dengan tanman karet di lahan kering masam. Tulisan disajikan pada Konferensi Nasional XV, Surakarta.

Badan Pusat Statistik. (2015). Statistik indonesia (statistical yearbook of indonesia) 2015. Jakarta, Indonesia: Badan Pusat Statistik.

Gomez, K. A., \& Gomes, A. A. (1995). Prosedur statistik untuk penelitian pertanian. Jakarta, Indonesia: Universitas Indonesia.

Kasniari, D. N., \& Supadma, A. A. N. (2007). Pengaruh pemberian beberapa dosis pupuk $(\mathrm{N}, \mathrm{P}, \mathrm{K})$ dan jenis pupuk alternatif terhadap hasil tanaman padi (Oryza sativa L.) dan kadar N, P, K inceptisol selemadeg, tabanan. Jurnal Agritop, 26(4), 168-176.

Notohadiprawiro, T. (2006). Ultisol, fakta dan implikasi pertaniannya. Pematangsiantar, Indonesia: Pusat Penelitian Marihat.

Paiman, A., \& Armando, Y. G. (2010). Potensi fisik dan kimia lahan marjinal untuk pengembangan pengusahaan tanaman melinjo dan karet di Provinsi Jambi. Jurnal Akta Agrosia, 13(1), 89-97.

Pansak, W. (2015). Assessing rubber intercropping strategies in northern thailand using the water, nutrient, light capture in agroforestry systems model. Kasetsart Journal, 49, 785-794.

Pirngadi, K., Toha, H. M., \& Guswara, A. (2012). Pemupukan NPK pada padi gogo sebagai tanaman sela perkebunan karet muda. Jurnal Soilren, 2(3), 133-141.

Pirngadi, K., Toha, H. M., \& Nuryanto, B. (2007, 19-20 November 2007). Pengaruh pemupukan $N$ terhadap pertumbuhan dan hasil padi gogo dataran sedang. Tulisan disajikan pada Apresiasi Hasil Penelitian Padi, Jakarta. 
Prasetyo, B. H., \& Suriadikarta, D. A. (2006). Karakteristik, potensi, dan teknologi pengelolaan tanah ultisol untuk pengembangan pertanian lahan kering di Indonesia. Jurnal Litbang Pertanian, 25(2), 39-47.

Putra, S. (2012). Pengaruh pupuk NPK tunggal, majemuk, dan pupuk daun terhadap peningkatan produksi padi gogo varietas situ patenggang. Jurnal Agritop, 2(1), 55-61.

Rodrigo, V. H. L., Silva, T. K., \& S, M. E. (2004). Improving the spatial arrangement of planting rubber (Hevea brasiliensis Muell. Arg.) for long-term intercropping. Field Crops Research, 89(2), 327-335.

Rodrigo, V. H. L., Stirling, C. M., Silva, T. U. K., \& Pathirana, P. D. (2005). The growth and yield of rubber at maturity is improved by intercropping with banana during the early stage of rubber cultivation. Field Crops Research, 91(1), 23-33.

Rosyid, M. J., Wibawa, G., \& Gunawan, A. (2012). Saptabina usahatani karet rakyat. In M. Lasminingsih, H. Suryaningtyas, C. Nancy, \& A. Vachlepi (Eds.), Pola tanaman sela. Palembang, Indonesia: Balai Penelitian Sembawa-Pusat Penelitian Karet.

Sahuri, \& Rosyid, M. (2015). Analisis usahatani dan optimasi pemanfaatan gawangan karet menggunakan cabai rawit sebagai tanaman sela. Warta Perkaretan, 34(2), 77-88.

Sahuri, Cahyo, A. N., \& Nugraha, I. S. (2016). Pola tumpangsari karet-padi sawah pada tingkat petani di lahan pasang surut, Sumatera Selatan. Warta Perkaretan, 35(2), 107-120.

Sahuri. (2017). Pengaturan pola tanam karet (Hevea brasiliensis Muell.Arg.) untuk tumpang sari jangka panjang. Jurnal Ilmu Pertanian Indonesia, 22(1), 443-462.
Santika, A. (2011). Teknik pengujian galur padi gogo terhadap keracunan aluminium di rumah kaca. Bulletin Teknik Pertanian, 16(2), 43-47.

Santika, A., \& Sunaryo. (2008). Teknik pengujian galur padi gogo terhadap penyakit blas (Pyricularia grisea). Bulletin Teknik Pertanian, 13(1), 5-8.

Santoso, B. (2006). Pemberdayaan lahan podsolik merah kuning dengan tanaman rosela (hibiscus sabdariffa 1.) di Kalimantan Selatan. Jurnal Perspektif, 5(1), 1-12.

Sasmita, P., Purwoko, B. S., Sujiprihati, S., Hanarida, I., \& Chozin, M. A. (2006). Evaluasi pertumbuhan dan produksi padi gogo haploid ganda toleran naungan dalam sistem tumpangsari. Bulletin Agronomi, 34(2), 79-86.

Sopandie, D., Trikoesoemaningtyas, Sulistyono, E., \& Heryani, N. (2002). Pengembangan kedelai sebagai tanaman sela: Fisiologi dan pemuliaan untuk toleransi terhadap naungan: Laporan Penelitian Hibah Bersaing. Diakses dari Dirjen Dikti, Kementerian Pendidikan.

Suwarno, H. M., Toha, \& Ismail, B. P. (2004, 15-18 Juli ). Ketersediaan teknologi dan peluang pengembangan padi gogo. Tulisan disajikan pada Seminar IPTEK Pekan Padi Nasional-II, Subang.

Syahputra, E., Fauzi, \& Razali. (2004). Karakteristik sifat kimia sub grup tanah ultisol di beberapa wilayah Sumatera Utara. Jurnal Agroteknologi, 4(1), 1796-1803.

Toha, H. M. (2005). Padi Gogo dan Pola Pengembangannya. Subang, Indonesia: Balai Penelitian Tanaman Padi.

Wibawa, G., \& Rosyid, M. (1995). Peningkatan produktivitas padi sebagai tanaman sela karet muda. Warta Perkaretan, 14(1), 40-46.

Wijaya, T. (2008). Kesesuaian tanah dan iklim untuk tanaman karet. Warta Perkaretan, 27(2), 34-44. 
Xianhai, Z., Mingdao, C., \& Weifu, L. (2014). Improving planting pattern for intercropping in the whole production span of rubber tree. Africa Journal of Biotechnology, 11(34), 8484-8490.
Zuraida, R. (2014, 6-7 Agustus 2014). Usahatani padi gogo di sela tanaman karet pada lahan kering bukaan baru di Kalimantan Selatan (Kasus di Desa Kiram Kabupaten Banjar Kalimantan Selatan). Tulisan disajikan pada Seminar Nasional "Inovasi Teknologi Pertanian Spesifik Lokasi, Banjarbaru. 